\title{
Autonomização dos poderes espiritual e temporal no Brasil do século XIX: extinção do padroado e secularização da esfera política
}

Gilson Ciarallo ${ }^{1}$

\section{Resumo}

Aspectos da secularização da esfera política no Brasil são colocados em perspectiva, salientando-se a relação entre a autonomização dos poderes espiritual e temporal e a extinção do padroado. Sobretudo ao longo da segunda metade do século XIX, circunstâncias e eventos históricos, tais como as querelas relativas à defesa do padroado. bem como as ideias ultramontanas explicitadas no episódio da Questão Religiosa contribuíram para a compreensão de rupturas e permanências nos campos das ideias políticas e das práticas sociais, o que permite o entendimento do processo de autonomização da esfera política no Brasil como individualidade histórica. Traço marcante dessa individualidade histórica é o descompasso entre as representações e práticas sociais presentes nos quadros do catolicismo popular e autonomização das esferas que se configura no plano da política em relação à religião.

Palavras-chave: Secularização. Padroado. Ultramontanismo. Questão religiosa. Catolicismo popular.

\section{Introdução}

Nas ciências sociais das últimas décadas, a secularização das instituições tem sido um tema bastante recorrente, principalmente, devido à sua complexidade conceitual e às diversas possibilidades de análise que a realidade sócio-histórica permite.

1 Doutor em Sociologia (UnB); professor de Sociologia e de Metodologia da Pesquisa no Centro Universitário de Brasília (UniCEUB); líder do grupo de pesquisa Epistemologia e tópicos metodológicos. gilsonciarallo@gmail.com. 
Secularização é um conceito que passou por diversas metamorfoses, tornando possível seu estudo genealógico (MARRAMAO, 1997), o que contribuiu em grande medida para a compreensão dos diversos significados que o termo ganhou ao longo do tempo. O significado mais recorrente da secularização nos estudos das ciências sociais é o que Dobbelaere $(1981,1999)$ classifica como secularização no nível macro. ${ }^{2}$ Nesse sentido estrito, secularização consiste na autonomização das esferas da sociedade em relação à religião. Segundo Dobbelaere (1999), cada subsistema da sociedade passa a produzir seus próprios valores e normas independentemente de normas religiosas neles vigentes anteriormente. São exemplos disso a emancipação da educação em relação à tutela eclesiástica, a separação entre Igreja e Estado, a rejeição dos dogmas da Igreja acerca do controle de natalidade e aborto, a evasão do conteúdo religioso anteriormente central na literatura e na arte, o desenvolvimento autônomo do conhecimento científico desvinculado de interesses religiosos.

Tal acepção da secularização está presente, por exemplo, nos estudos de Berger (1985, p. 119), que a entende como,

[...] processo pelo qual setores da sociedade e da cultura são subtraídos à dominação das instituições e símbolos religiosos", manifestando-se na "retirada das Igrejas cristãs de áreas que antes estavam sob seu controle ou influência: separação da Igreja e do Estado, expropriação das terras da Igreja, ou emancipação da educação do poder eclesiástico.

No Brasil, o processo de secularização da esfera política esteve intimamente ligado à extinção do padroado, o que ocorre como decorrência do processo de autonomização dos poderes temporal e espiritual. A análise de circunstâncias e eventos históricos específicos, localizados, sobretudo, na segunda metade do século XIX, contribui para a compreensão desse processo de secularização da esfera política no Brasil, a qual é entendida neste trabalho, como individualidade histó-

\footnotetext{
2 A fim de dar conta da complexidade intrínseca ao conceito, há que se levar em conta a distinção de níveis de análise da secularização que se foram constituindo no métier da reflexão em sociologia da religião. Seguindo de perto a sistematização de Dobbelaere (1981, 1999), a secularização tem acepções que devem ser situadas em três níveis de análise distintos: o macro, o meso e o micro.
} 
rica. É com este propósito que serão discutidos e analisados tais eventos e circunstâncias nos próximos parágrafos.

O Brasil nasce sob a égide do padroado. Tal consideração é imprescindível nos quadros de reflexão que têm como objeto a história das relações entre Igreja e Estado no Brasil. Assim, é por ser este regime, o padroado, constitutivo do próprio cenário no qual aquelas esferas se constituem e se ajustam umas às outras, para além do período colonial:

[...] do pacto do padroado, com as interpretações que lhe dá a Coroa portuguesa, resultam as acidentadas relações da Igreja com o Estado, durante os séculos XVI e XIX no Brasil, e muito das formas que no país assumiu a religiosidade católica (AZEVEDO, 1978, p. 27).

A obra de Thales de Azevedo, cujo trecho foi citado acima, tem como título Igreja e Estado em tensão e crise. É dividida em duas partes: "A Conquista Espiritual" e "O Regímen do Padroado". Esta última ocupa mais da metade do livro, estendendo-se até 1890, com o advento da República. Extensão que aponta para uma realidade fundamental das relações entre Igreja e Estado no Brasil: a maior parte da história das relações entre estas duas esferas está marcada por uma fusão de competências e significados, a qual tem raízes na gênese desta realidade sócio-cultural que se compõe nos trópicos.

Instituição atrelada ao período de reconquista ibérica, o padroado surge como um compromisso entre a Santa Sé e o governo português, do qual decorria o direito da Coroa portuguesa de administrar os negócios eclesiásticos de seus domínios, direito originariamente concedido pelos papas aos reis de Portugal mediante bulas diversas. ${ }^{3}$

Desde D. Manuel, os reis acumularam a Coroa com o mestrado das ordens religioso-militares, entre as quais a Ordem de Cristo. A ela cabia a arrecadação dos dízimos e sua aplicação, tornando-se, como sustenta Lacombe (1989), recur-

3 O papa Nicolau V enviou ao rei Afonso de Portugal a bula Romanus Pontifex em 8 de janeiro de 1455. Nela reconhecia as conquistas de Portugal contra os infiéis e conferia à Coroa lusa direitos exclusivos para reivindicar para si as "regiões meridionais", 
sos financeiros dos mais importantes para a expansão porturguesa, sendo mantidos no Império brasileiro. ${ }^{4}$ Além das competências de arrecadação e aplicação dos dízimos, o prior da Ordem de Cristo poderia conferir benefícios eclesiásticos diversos a quem lhe conviesse, bem como exercer jurisdição espiritual sobre padres seculares e regulares nas regiões sob seu domínio. Estas, por sua vez, ficavam desincorporadas de qualquer bispado. Tais competências estiveram sempre muito bem contempladas nos quadros de dominação dos estadistas portugueses, os quais muitas vezes agiam segundo princípios doutrinários denominados regalistas. ${ }^{5}$

Coletados e administrados pela Coroa, dos dízimos provinham os recursos para construção de matrizes, fundação de conventos, pagamento de côngruas dos bispos e cônegos, dos párocos e seus coadjutores, bem como subvenções a ordens religiosas. O grão-mestre da ordem era, portanto, o tesoureiro e o administrador dos recursos da Igreja no ultramar. A concessão e reafirmação para o Imperador do Brasil do direito de arrecadação e administração dos dízimos vinham atadas ao encargo de conservar e propagar a fé, sobretudo, entre os povos indígenas, bem como garantir manutenção digna ao episcopado, ao clero e aos institutos religiosos.

realçando a natureza missionária do empreendimento exploratório. O mesmo rei Afonso recebeu a bula Inter Caetera do papa Calixto II, de 13 de março de 1456, que não apenas confirmava os privilégios anteriores, mas também conferia à Ordem de Cristo bens e direitos eclesiásticos sobre todas as conquistas lusas presentes e futuras. Na Aeterni Regis, de 21 de junho de 1481, o papa Xisto IV confirmava os privilégios atribuídos anteriormente por Nicolau V. A Inter Caetera, de 4 de maio de 1493, inicia-se com apelo de cruzada. Na Providum universalis, de 29 de abril de 1514, Leão X confirmava a D. Manoel e seus sucessores a posse dos patrimônios eclesiásticos do reino e das conquistas, para continuação da guerra contra os infiéis. Na Dum fidei constantiam, de 7 de junho de 1514, o pontífice incorporava todas as igrejas de ultramar à Ordem de Cristo, concedendo a D. Manoel o direito de padroado sobre essas igrejas. Cf. O império marítimo português 1415-1825, de C. R. Boxer (2002).

4 Até desaparecerem, com o advento das reformas fiscais, foram cobrados regularmente, até 1832 - no Maranhão, até 1835 -, os dízimos do açúcar, do algodão, do café, do tabaco, do fumo e do gado.

5 Consistindo, basicamente, na reivindicação de Igrejas nacionais, o regalismo refere-se a princípios que afirmavam o poder da Igreja local em detrimento do poder da Santa Sé. Seu uso remonta a eventos específicos ocorridos na França do século XVII: intolerante em relação aos protestantes e jansenistas, o rei Luís XIV considerou ofensiva a oposição do Papa à atitude adotada no caso das chamadas regalias ou realengo (régales), que são direitos que a Coroa francesa reivindicava sobre certos mosteiros e bispados vagos. 
Em Portugal, os tributos de caráter religioso foram suprimidos em 1832. No Brasil, mesmo perdendo força, foram mantidos durante o Império, desaparecendo definitivamente apenas com o advento da República, momento em que o próprio padroado é institucionalmente extinto.

A continuidade da instituição do padroado para além do período colonial é um dos indicadores de um recrudescimento da fusão das competências características da esfera estatal e religiosa, abarcadas num mesmo quadro de exercício de poder no Império brasileiro. É de 1827 a bula Praeclara Portugalliae, do Papa Leão XII, que reconhecia ao Imperador brasileiro a chefia da Ordem de Cristo, destacada daquela portuguesa. Transferia-se, dessa forma, ao chefe do Estado brasileiro, todos os privilégios dos quais gozava o soberano português. Pertence a este contexto um dos eventos que traduz bem a fusão entre aquelas esferas: tendo sido submetida à Câmara dos Deputados ${ }^{6}$ - uma vez que a Constituição do Império exigia o placet para o cumprimento dos atos pontifícios, procedimento este previsto pelo processo legislativo - a bula foi rejeitada, já que, como príncipe cristão, concluíam os parlamentares -, cabia ao imperador o exercício do padroado, independentemente de qualquer concessão pontifícia. Conforme registrado no relatório da Comissão de Negócios Eclesiásticos, a bula "[...] conferia ao imperador direitos que ele já tinha por títulos mais nobres”, sendo então considerada ofensiva à Constituição do Império. A partir de então, o padroado passava a ser considerado como direito próprio do principado civil, e não mais uma concessão do Papa.

De fato, a Carta de 1824 relacionava entre os poderes do Imperador, na condição de chefe do Poder Executivo, o exercício das seguintes atribuições por intermédio de seus ministros de Estado: "Nomear Bispos e prover os Benefícios Eclesiásticos." (Art. 102, II); “Conceder ou negar o Beneplácito aos Decretos dos Concílios, e Letras Apostólicas, e quaisquer outras Constituições Eclesiásticas, que não se opuserem à Constituição; e procedendo aprovação da Assembleia, se contiverem disposição geral.” (Art. 102, XIV). Numa atitude explicitamente regalista, o

6 Internamente, a Câmara dos Deputados submeteu o documento à comissão técnica competente, nesse caso específico de Constituição e de Negócios Eclesiásticos. O relatório da Comissão de Negócios Eclesiásticos recomendou a rejeição da bula ao plenário da Câmara, a qual seguiu para a sessão de 16 de outubro de 1827 . 
poder temporal se apropriava do poder espiritual a fim de fazer valer sua própria sacralidade. Na verdade, estes dois poderes, nos quadros do padroado do Império do Brasil, não se distinguiam de maneira clara, estando imersos num mesmo quadro de exercício de poder político. Nos mesmos termos utilizados por um dos historiadores do pensamento católico brasileiro, trono e altar se apresentavam no Brasil do século XIX como um binômio indissolúvel (AZZI, 1992).

À primeira vista, o quadro geral que se apresenta, considerando a instituição do padroado e a fusão das esferas temporal e espiritual, parece privilegiar a posição dos eclesiásticos, garantindo-lhes privilégios, poder político e prestígio. No entanto, tal percepção não assegura uma visão clara da conjugação que de fato se opera. $\mathrm{O}$ que efetivamente se tem é a ingerência do poder temporal no espiritual, subsumindo-o em seu âmbito de exercício de poder e subtraindo-o dos eclesiásticos - em cujas mãos estivera originalmente - que, submetidos à Coroa, assemelhavam-se a outros funcionários do Estado. Nas palavras de Hauck, os eclesiásticos eram:

[...] funcionários de uma religião de Estado agressivamente única, vindos de fora quase todos, sem identificação com o povo que deviam reger e ensinar. Por parte das autoridades civis era tão abrangente o conceito de padroado que nem se pode falar da Igreja como instituição distinta do poder absoluto do Estado, que absorvia a religião como uma de suas instituições fundamentais (HAUCK, 1980, p. 15).

Incorporada ao Estado, a Igreja Católica brasileira desse período é ainda considerada como "ramo da administração pública" (MENCK, 1995, p. 43). O cenário que se forma é conflitivo, gerando uma série de impasses reveladores da tensão que marca todo o período monárquico pós-independência. Dois motivos desses impasses se apresentam nitidamente. Primeiro, os eclesiáticos sentiam-se usurpados quanto ao que lhes era concedido em termos de seu exercício de poder, daquilo que, no âmbito próprio do poder espiritual, era-lhes facultado decidir. Segundo, os vencimentos pagos a título de côngruas não eram suficientes com vistas à sustentação regular dos eclesiásticos. ${ }^{7}$ Eram obrigados, então, a complementar o salário, seja por meio de contribuições (denominadas benesses, conhecenças, di-

De acordo com Lacombe (1989, p. 120), “[...] no princípio do século XVIII o bispo da Bahia recebia para sua manutenção, bem como de toda a cúria, 1:250\$000 anuais. 
reito de estola ou pé de altar) dos próprios paroquianos, seja dedicando-se a outras profissões: havia padres, fazendeiros, advogados, donos de hotéis, donos de postos de ferrar cavalos, mineradores. Quanto a essa variedade de ocupações, ressalte-se o espanto e horror sentidos pelo viajante Saint-Hilaire diante do abandono espiritual em que se deixava o rebanho de fiéis. É a esse viajante francês que Caio Prado Júnior (2002, p. 1384) se reportou em Formação do Brasil contemporâneo, sustentando que os eclesiásticos não eram moradores fixos dos povoados, acrescentando às suas funções sacerdotais "outras mais terrenas de fazendeiro ou minerador".

Quanto à primeira das razões, cabe ressaltar que, outorgada a Constituição de 1824, o controle das autoridades governamentais sobre a Igreja aumentou em grande medida. Instituição régia transferida para o Brasil com a vinda da Família Real, a Mesa da Consciência e Ordens ${ }^{8}$ continuou a administrar o provimento do clero e outros assuntos eclesiásticos até 1828. Tais funções passaram, então, a fazer parte das competências do Ministério da Justiça, o qual as passou, logo após, em 1861, para o Ministério do Império. Nesse período de tempo, o processo decisório referente aos assuntos religiosos e eclesiásticos esteve inteiramente sob o controle do Estado: nomearam-se párocos; negou-se à Santa Sé o recebimento de recursos provenientes dos fiéis; limitaram-se as funções episcopais; inibiu-se a criação de novas dioceses; permitiu-se recurso de apelação aos magistrados seculares sobre decisões dos tribunais eclesiásticos; proibiram-se ordens religiosas de receberem noviços; regulamentaram-se seminários; fez-se uso da paróquia como extensão da

Em meados do século tal despesa elevara-se a 2:230\$000. Para o cabido inteiro não se destinavam mais que $448 \$ 000$ por ano, muito embora os dízimos da Bahia chegassem a render 150.000 cruzados. A côngrua dos párocos não passava, a princípio, de $35 \$ 000$ anuais. Em 1608 passou a 50\$000. No século XVII um pároco efetivo não recebia mais de $200 \$ 000$ anuais e $40 \$ 000$ para a administração da matriz. O mesmo se pagava na Paraíba. Mas em Itamaracá não passava de 35\$000. O seminário dispunha de $120 \$ 000$ anuais. Os vencimentos eram pagos por trimestres e estavam sempre em atraso. Já em 1863, a Igreja recebera, pelo orçamento do império, cerca de 1.000:000\$000 anuais, muito abaixo do que renderiam os dízimos regularmente cobrados".

8 Instituição criada em 1532, incorporou a administração das ordens militares em 1551. Provisões de fins do século XVIII e inícios do XIX criaram o arcabouço jurídico que permitiu à Mesa da Consciência e Ordens tratar de assuntos diversos, dentre os quais aqueles referentes ao clero e ao culto. Guilherme Pereira das Neves em E receberá mercê analisa detidamente o papel dessa instituição no período em que funcionou no Brasil. 
vida política e civil; legislou-se sobre divisões eclesiásticas, conventos e associações religiosas, tais como as irmandades; interferiu-se em construções de igrejas e capelas, na organização de devoções e de festas religiosas.

Paladino do ultramontanismo, ${ }^{9}$ com formação na França e em Roma, o Bispo do Pará, Dom Antônio de Macedo Costa, foi um dos protagonistas nos embates que emergiram por conta dessa fusão de competências nas mãos do poder temporal. Em "Memória" datada de 28 de julho de 1863, dirige-se ao imperador, insurgindo-se contra a ingerência do Estado nos assuntos religiosos:

De há muito, Senhor, os Bispos do Brasil somos contristados com Avisos e Decretos restritivos da liberdade e independência do nosso sagrado ministério; de há muito notamos com mágoa a funesta tendência do governo a ingerir-se na economia da Igreja como se procurasse reduzi-la pouco a pouco à condição de um estabelecimento humano, a um mero ramo da administração civil. Parecem não ser mais os Bispos do Brasil que funcionários públicos, sujeitos ao Conselho de Estado, que à imitação da célebre Mesa de Consciência e Ordens, decide em última instância as questões mais graves do direito canônico e da administração eclesiástica dignando-se às vezes consultar os Prelados como meros informantes. A catequese, a residência dos Párocos, o noviciado dos conventos, administração das Igrejas deles, os estatutos das Catedrais e dos Seminários, a organização que se deve dar a estes últimos estabelecimentos, e até os nomes que lhes competem, as condições que se devem exigir para admissão às Ordens, tudo isso julga o Governo ser de sua alçada, sobretudo isto se crê com direito de decidir, de decretar e legislar (PEREIRA, 1970, p. 36).

Escravidão, e escravidão ignominiosa, é o que quereis impor com vossas teorias do Estado pagão, do Estado sem Deus, do Estado fonte e critério de todos os direitos, absorvendo o cidadão todo inteiro... Escravidão, dura e ignominiosa

9 Termo utilizado desde o século XI, referindo-se aos cristãos que buscavam a liderança de Roma (do outro lado da montanha). É relativo também à defesa do ponto de vista dos papas, aos que davam apoio à política papal, frequentemente em oposição aos partidários do imperador. O tipo de pensamento que no século XIX é conhecido como ultramontanismo refere-se aos conceitos e atitudes conservadores da Igreja, geralmente opondo-se às correntes liberais que emergiram a partir da Revolução Francesa. Nesse sentido, ser ultramontano é ser ortodoxo, é pautar-se nos ditames doutrinários propugnados pelas bulas romanas, independentemente das correntes de pensamento locais. 
escravidão, é esse Estado civil de mitra e báculo, governando a Igreja (FRAGOSO, 1980, p. 185).

Nas palavras de D. Macedo Costa, tornam-se explícitas as particularidades daquela fusão de competências nas mãos do Estado, dando a nítida impressão da sujeição, da heteronomia que marca as relações entre as duas esferas em questão. Em carta ao Senador Ambrósio Leitão da Cunha, assim desabafava o Bispo do Pará: “A Religião não é alfândega, a Religião não é eleição, a Religião não é guarda nacional, a Religião não é repartição civil, que o Governo possa dirigir, mandar e arranjar a seu jeito" (VILLAÇA, 1974, p. 2).

Também paladino do ultramontanismo, Cândido Mendes de Almeida ${ }^{10}$ é outro dos que, em seu Direito civil eclesiástico brasileiro, protestam contra aquela fusão de competências, atacando diretamente a instituição do padroado:

A Igreja fundou o Padroado no interesse do seu serviço, e sem prejuízo de sua liberdade. Encheu de privilégios e de graças aqueles a quem honrava com o título de Padroeiros, não julgando que seus advogados e paladinos se quisessem constituir não só seus dominadores, como perseguidores, muitas vezes impondo-se tais encargos como regalias por efeito do próprio arbítrio, sem consultarem a protegida, e a despeito de sua vontade e protestos. Mas o propósito era, e sempre tem sido, arrancar à Igreja sua liberdade, para modelá-la em instrumento de governo e de domínio, realizando-se assim o grande pensamento do Cesarismo. (VILLAÇA, 1981, p. 12).

O movimento em direção à supressão das vinculações entre as duas esferas inclui, portanto, a reclamação dos eclesiásticos pela autonomia nos processos decisórios referentes aos assuntos religiosos. Nesse sentido, há, paradoxalmente, um movimento secularizante originário do pensamento eclesiástico brasileiro no século XIX: ao querer autonomia para as decisões relativas aos assuntos religiosos, a desvinculação das esferas, com o advento da República, veio a ser um "mal neces-

${ }^{10}$ Político e jurista brasileiro do Segundo Império, Cândido Mendes foi deputado por diversas legislaturas e senador do Império a partir de 1871. Apresentou-se como defensor dos bispos brasileiros envolvidos na questão religiosa do final do Segundo Império e construiu a extensa base jurídica da disputa entre ultramontanos e a Coroa pelos direitos tradicionais da Igreja. É lembrado por David G. Vieira (1980) pela sua luta contra o galicanismo - (definição de direitos disciplinares próprios, independentes de Roma) através de seu estudo de quatro volumes sobre as legislações portuguesas e brasileiras. 
sário" aos olhos dos eclesiásticos. É assim que se pode entrever certa ambiguidade nos discursos a que se tem acesso: ao passo que se verificam protestos apaixonados contra a laicização do Estado e separação total entre as esferas; há o rejúbilo inflamado diante da derrota do regalismo, o qual, nos termos da pastoral coletiva de 19 de março de 1890, se via "com direito de governar a Igreja em nome do padroado e do grão-mestrado".

Por outro lado, o advento da República acarretaria a dissolução dos tronos, o que parecia abalar os alicerces da Igreja, já que essas duas esferas estavam há séculos imbricadas e envoltas em aura sagrada, mantendo afinidades de símbolos e sentidos característicos da esfera espiritual. Nesse contexto, surgem manifestações contra a dessacralização da autoridade estatal, um resultado decorrente da futura extinção do padroado. José Soriano de Souza, ${ }^{11}$ participante do movimento tradicionalista de Pernambuco, manifestava-se contra tal dessacralização em Lições de filosofia elementar racional e moral, de 1871, denunciando as consequências do liberalismo burguês:

As lutas intentadas contra o poder em nome da liberdade, e a dos poderes da terra contra o poder divino, e como conseqüência natural a falta de respeito e amor à pessoa sagrada dos imperantes, os ungidos do Senhor. Então o Estado não é mais como uma grande família, nem os súditos como filhos, nem os monarcas como pais (LARA, 1988, p. 80).

O jornal A Esperança, ao ser lançado por intelectuais católicos do Recife - dentre os quais, José Soriano de Souza -, em dezembro de 1864, traz uma manifestação de defesa à origem sagrada da autoridade, diante das vagas de dessacralização que já ameaçavam o cenário do trono imperial:

Consideraremos, pois, sempre o monarca como ministro de Deus para o bem, ministrum Dei in bonum, segundo a frase do Apóstolo; e neste sentido, trabalharemos com vigor por manter ilesas e não sofismadas as suas altas prerrogativas (LARA, 1988, p. 74).

\footnotetext{
${ }^{11}$ Ao lado do Senador Cândido Mendes de Almeida, José Soriano de Souza é citado por David Gueiros Vieira (1980) como importante paladino do ultramontanismo no período anterior ao advento da República. É ainda conhecido pelos seus esforços em restabelecer no Brasil as bases filosóficas e teológicas do tomismo.
} 
O pensamento conservador, representado nos trechos acima, são reações à ameaça das correntes liberais que se estendiam ao longo do século XIX, alcançando inclusive o cenário nacional. ${ }^{12}$ Sempre em defesa da liberdade, da emancipação e afirmação do indivíduo, as ideias liberais eram favoráveis a intervenções em todas as esferas que proporcionassem obstáculos à sua livre expressão, visando a livrá-lo do dogmatismo, sobretudo aquele da Igreja Católica. Constitutiva do conjunto de ideias liberais, a busca pelo melhoramento tecnológico, entendido como "progresso", requeria do Estado a abertura do país a novas possibilidades de exploração econômica com vistas ao desenvolvimento da nação.

As vagas do liberalismo iriam se defrontar com o conservadorismo ultramontano, o qual reagia utilizando-se dos instrumentos da imprensa de orientação liberal. O editorial de 19 de junho de 1852 do jornal O Velho Brado do Amazonas é expressivo dessa reação liberal, referindo-se ao padre Eutychio Pereira da Rocha, na ocasião em que fora chamado a ser colaborador do bispo do Pará:

Custaria a crer, se não se visse, que no século XIX, e no Brasil, aparecesse um sacerdote, importado para o ensino das instituições canônicas, sustentando em público essas sediças doutrinas ultramontanas, subversivas das sociedades políticas, que vogaram nesses tenebrosos tempos em que os chefes da Igreja, abusando da religião santa de Jesus Cristo, destronizaram Reis, destruíram Estados, e proclamaram que um simples exorcista excedia tanto a um rei quanto um homem excedia a uma fera. Nestes tempos tenebrosos em que a ambição sacerdotal a ferro, fogo e sangue que o poder espiritual da Igreja devia dominar o temporal e não estar sujeito a este.

Ressalte-se que a propagação das ideias liberais no Brasil esteve intimamente ligada à ação da Maçonaria, ${ }^{13}$ a qual, uma vez comprometida com aquela noção de "progresso", concebia a Igreja Católica como símbolo do atraso medieval. A

${ }^{12}$ O liberalismo brasileiro do século XIX obteve fortes influências das ideias liberais inglesas. O sistema político britânico esteve em evidência no momento de elaboração das instituições brasileiras. Vale citar os esforços do maçom Hipólito José da Costa Pereira Furtado de Mendonça, o qual iniciou, em junho de 1808, a publicação do Correio Braziliense, no qual divulgava documentos oficiais e expunha suas ideias liberais, em oposição às práticas do Antigo Regime, influenciando decisivamente o jornalismo da Independência.

${ }^{13}$ Identificada pela historiografia como sendo o embrião do reino da crítica, ou como a inauguração de um espaço público moderno, a maçonaria trouxe para o seu seio discussões 
Igreja Católica, por sua vez, na sua vertente ultramontana, sentia-se incomodada diante do caráter ecumênico da maçonaria, em cujo programa de ação característico das lojas mais conservadoras se incluíam os seguintes objetivos:

a)conservar a nação unida a qualquer preço, usando o Trono como seu ponto de apoio; b) controlar a Igreja, conservando-a liberal, dominada pela Coroa, com um clero não educado [ou educado em quadros iluministas] e, sobretudo, não ultramontano; e c) lutar pelo "progresso" do Brasil por meio do desenvolvimento da educação leiga, da expansão do conhecimento científico e técnico (não estorvado pela teologia) e da importação de imigrantes "progressistas" e tecnicamente educados, dos Estados Germânicos, da Inglaterra e de outras nações protestantes. (VIEIRA, 1980, p. 46).

Diante de tal frente de ação, seriam frequentes os ataques aos maçons nas publicações eclesiásticas. Atos por parte dos eclesiásticos ultramontanos chegaram a exigir abjurações forçadas de maçons necessitados dos serviços religiosos. Castellani (1996, p. 105-106) cita o caso do maçom Antonio de Freitas e Silva, o qual, em 23 de junho de 1874, registrava a seguinte Pública-Forma:

Eu, abaixo assinado Antonio de Freitas e Silva declaro que se abjurei a Maçonaria não foi porque seja ella contraria á religião de Christo mas sim porque achando-me doente e desejando me confessar e sacramentar, mandei chamar o vigario desta freguezia, que declarou-me não me confessaria sem que eu jurasse em como não pertenceria mais á Maçonaria pelo que assim procedi, sendo certo que só obrigado como fui pelo dicto vigario assim procederia. E para constar e ser verdade mandei passar a presente declaração que assigno com estas testemunhas abaixo.

conduzidas de maneira independente do círculo de dominação da corte. No Brasil do século XIX, são fundadas as lojas União, de 1800, as lojas Constância e Filantropia, de 1804, a loja Grande Oriente Brasileiro e a loja Apostolado da Nobre Ordem dos Cavaleiros de Santa Cruz. Houve lojas ligadas à Corte: a ultramonarquista Bouclier d'Honneur e a Vigilância da Pátria, de tendência liberal. A atitude ousada que se opunha aos governos, característica da maçonaria de tendência mais liberal, pode também ser representada pela Grande Loja Brasileira, fundada em 1831 e pela Grande Oriente. No Segundo Reinado, a Grande Oriente do Brasil organiza-se mais sistematicamente, rivalizando mais tarde com a Grande Oriente. É entre maio e setembro de 1872 que estas duas lojas se unem na formação do Grande Oriente Unido e Supremo Conselho do Brasil, visando a enfrentar conjuntamente os ataques do ultramontanismo, no contexto que culminou na Questão Religiosa. 
Nova Friburgo, vinte e trez de Junho de mil outo centos e setenta e quatro. Antonio de Freitas e Silva, Joaquim Maria de Mello Costa, Antonio Ferreira Gomes, José da Silva Neves, Francisco Xavier Saraiva e José Joaquim de Oliveira Marzagão.

No quadro que se vai delineando, duas correntes de pensamento se opõem nesse contexto. De um lado, um recrudescente e reacionário conservadorismo católico; de outro, as vagas de um liberalismo que se impunha a todos os obstáculos, forçando as portas para a chegada do que seria uma nova era, de novos tempos, do progresso, enfim. Tais obstáculos tinham suas raízes fortalecidas, alimentando-se da efervescência que tomava conta da Igreja de Roma: a presença predominante de ideias ultramontanas no seio da elite eclesiástica brasileira acompanhava e refletia o movimento católico antiliberal centralizado em Roma, sobretudo após a publicação do compêndio Syllabus, anexado à encíclica Quanta Cura. ${ }^{14}$

Publicado por Pio XI em 1864, o Syllabus, escrito de maneira clara e acessível aos leigos, é conhecido como "católogo dos erros modernos", causando grande repercussão no mundo católico. Anatematizando a civilização moderna, Pio XI se manifestava como autoridade incontestável. Em suas próprias palavras: “Se, sob o nome de civilização, se deve entender um sistema inventado precisamente para enfraquecer a Igreja e por ventura destruí-la, jamais a Santa Sé ou o Pontífice Romano poderão aliar-se a tal civilização!” (MENCK, 1995, p. 13). A encíclica, de forma geral, e o Syllabus, especificamente, externalizavam a defesa da Igreja contra as correntes de pensamento modernas, como o racionalismo, o naturalismo e o próprio liberalismo. Ao rejeitar dessa forma as bases do pensamento liberal, opunha-se à liberdade de culto e de expressão, à criação de instituições laicas - como o registro e o casamento civis -, à separação entre Estado e Igreja, à educação totalmente leiga, à equivalência das religiões etc.

${ }^{14}$ Composto por 80 sentenças distribuídas em 10 parágrafos, o Syllabus aborda os seguintes temas: $\$ 1^{\circ}$. Panteísmo, naturalismo, racionalismo absoluto; $\$ 2^{\circ}$. Racionalismo moderado; $\$ 3^{\circ}$. Indiferentismo, latitudinarismo (laxismo ou liberalismo moral); $\$ 4^{\circ}$. Socialismo, comunismo, sociedades clandestinas, sociedades bíblicas, sociedades clérico-liberais; $\$ 5^{\circ}$. Erros sobre a Igreja e seus direitos; $\$ 6^{\circ}$. Erros sobre a sociedade civil considerada em si e em suas relações com a Igreja; $\$ 7^{\circ}$. Erros sobre a ética natural e a ética cristã; $\$ 8^{\circ}$. Erros sobre o matrimônio cristão; $\$ 9^{\circ}$. Erros sobre o poder temporal do Pontífice Máximo; $\$ 10^{\circ}$. Erros que se referem ao liberalismo do século XIX. 
Completando o quadro da reação da Igreja romana aos "erros da modernidade", Pio IX, além de condenar a Maçonaria, responsabilizando-a pela impiedade que aos seus olhos crescia em todo o mundo, convocou o primeiro Concílio Vaticano (1869-1870), no qual seria proclamado o dogma da infalibilidade papal. Dessa forma, conseguia o Papa impor decisivamente sua autoridade sobre toda a Igreja, não sem objeções, porém. ${ }^{15}$

Ao amadurecer suas ideias acerca da liberdade religiosa e da necessidade de separação entre a Igreja e o Estado, Rui Barbosa vislumbrava a importância da tradução para o português do livro de Döllinger, O Papa e o Concílio (1869-70/1877). Ocupando dois terços de um total de dois volumes, a introdução de Rui Barbosa à tradução - também sua - expressava o posicionamento dos liberais brasileiros diante da reação católica aos tempos modernos, bem como a sua orientação ultramontana no Brasil. No prefácio da tradução, Rui Barbosa frisava "a ignorância palmar dos que reputam facultativa aos catholicos romanistas a adesão ao Syllabus", restando "provada a incompatibilidade philosófica e praticamente inconciliável entre esse abominável symbolo da papolatria e qualquer constituição moderna, especificamente a nossa" (BARBOSA, 2002, p. 14).

Compunha-se, assim, o quadro no bojo do qual se traçavam as linhas gerais da reação da Igreja Romana, em cujas bases o catolicismo brasileiro de orientação ultramontana se insurgia contra o galopante liberalismo, procurando revigorar os laços com Roma. A esse respeito, atente-se para o discurso do ultramontano D. Macedo Costa em 15 de junho de 1877, por ocasião do jubileu de Pio IX:

É preciso condenar a maçonaria, tornada uma potência formidável neste século? Não uma, mas muitas vezes caiu sobre a cabeça da seita perversa o vosso anátema, sem receio algum de suas iníquas tramas. É preciso reduzir a

\footnotetext{
${ }^{15}$ Oitenta e oito bispos votaram contra a definição na primeira votação e cinquenta e cinco se ausentaram da votação final, em 18 de julho de 1870. Dentre as manifestações contrárias à definição do dogma, cite-se a de Döllinger em O Papa e o Concílio (1869-70), traduzida no Brasil por Rui Barbosa, em 1877 e novamente publicada pela editora Leopoldo Machado, em 2002. Historiador eclesiástico e teólogo liberal de Munique, Döllinger protestava contra o crescente absolutismo papal e o reavivamento da teologia escolástica. Manteve-se em oposição ao dogma da Infalibilidade papal, o que lhe custou a excomunhão, em 1871.
} 
um feixe, e fulminar juntos todos os erros modernos? Mas que frêmito horroroso entre os povos! Como as potências da terra irão opor-se a que se lhes quebrem os dourados ídolos! Que tem isso? O Syllabus aparece, e os princípios da eterna verdade, da eterna justiça, os fundamentos da ordem religiosa e moral brilham sobre os horizontes intelectuais do mundo com um fulgor tão sereno como irresistível. É preciso reunir-se o concílio ecumênico e declarar o dogma do infalível magistério do sucessor de são Pedro? Levantemse montanhas de dificuldades; revolvam-se as paixões dos homens... Vós não sois pontícife de reter a verdade cativa em vossos lábios, por vãos receios humanos; proferis a definição. Graças a vós, temos o farol para a noite que se vai cada vez mais condensando sobre o mundo ${ }^{16}$ (LUSTOSA, 1939 apud AZZI, 1992, p. 118).

Saliente-se a formação, nos quadros da Igreja, de uma autoconsciência de sua própria santidade (FRAGOSO, 1980, p. 145), em contraste com um mundo sombrio e maligno, imerso em trevas. Insurgir-se contra os inimigos da fé, materializados pela frente liberal que avançava, mantinha repleta de sentido a ação missionária ultramontana. Afinal era a Igreja a portadora da verdade, colocando-se defronte dos erros da modernidade, enfrentando-os. O Syllabus, o dogma da infalibilidade papal e a anatematização da Maçonaria vinham para prover alicerces mais sólidos a tal missão contra o mal, a qual assim expressa o mesmo D. Macedo Costa (1870 apud FRAGOSO, 1980, p. 144-145): "Parece estar o inferno em peso desencadeado e solto, desesperado contra a Igreja, atacando-a nos paroxismos de uma raiva que talvez nunca se viu o triste espetáculo em países católicos. Mas non praevalebunt". Com efeito, os mais influentes paladinos do ultramontanismo no Brasil do século XIX reúnem algumas das características próprias do profeta, levando em conta o tipo ideal weberiano: diante da situação da qual se aproxima o inferno, imbuem-se de uma autoridade sustentada por uma missão, por um mandado divino - através da infalível palavra papal - que os levam a querer reformar a realidade a partir de uma ética suprema, usurpadora até mesmo do poder político e visando à transformação das relações sociais.

Constitutivo do quadro supracitado, um evento específico toma forma, representando bem os impasses que no início da década de setenta (1872-75) do

\footnotetext{
${ }^{16}$ Trecho da compilação Dom Macedo Costa, de Antônio de Almeida Lustosa.
} 
século XIX marcaram as relações entre o Estado e a Igreja brasileiros. Conhecido como a Questão Religiosa, um conflito de jurisdição dos bispos do Pará (D. Macedo Costa) e de Pernambuco (D. Vital) com o poder civil ganha proporções consideráveis, envolvendo a Maçonaria brasileira, o episcopado, a imprensa e parte considerável da população. Um olhar atento para esse conflito permite um acesso efetivo às linhas gerais das relações entre as distintas esferas que aqui são analisadas. Em outras palavras, a conjugação dos eventos que efetivamente compuseram a Questão Religiosa, a trama engendrada, os diversos movimentos entre os atores e instituições que nela estiveram - ativa ou passivamente - envolvidos, bem como as relações de dominação que ali se entrecruzaram, ilustram o quadro geral que se foi compondo na segunda metade do século XIX, rumo a transformações profundas: de um poder estatal marcado pelo regalismo a outro autônomo em relação à Igreja e à religião, em termos gerais.

Um fato específico prefigurou o conflito: em março de 1872, a loja maçônica do Rio de Janeiro Grande Oriente do Lavradio escolhia o padre Almeida Martins como orador por ocasião da homenagem ao grão-mestre Visconde do Rio Branco, visando à celebração da assinatura da Lei do Ventre Livre. Ao ser publicado, o discurso causou grande escândalo. O bispo D. Pedro de Lacerda é então levado a suspender o padre Almeida das ordens, provocando protestos por parte dos maçons, indignados diante do que consideravam ser interferência da Igreja nos assuntos do país.

Ostentando credenciais ultramontanas, seria D. Vital Maria Golçalves de Oliveira, seguido por D. Macedo Costa, o principal agente desencadeador do conflito, ao proibir, por meio de uma circular, a participação de eclesiásticos em qualquer cerimônia maçônica. Em maio de 1873, D. Vital (e posteriormente D. Macedo) suspendia várias irmandades e ordens terceiras que, desobedecendo ao bispo, negaram-se a afastar de seu seio os membros maçons. Apelando ao Imperador, já que poderiam se valer do recurso à Coroa na qualidade de tribunal superior, as irmandades, ao se apresentarem como associações mistas (religiosas e civis), requeriam a intervenção do Governo. Ademais, as bulas pontifícias que condenavam a maçonaria não tinham validade no Brasil, pois careciam do beneplácito imperial. Acolhido o recurso, o imperador, por intermédio de seu ministro do império, diri- 
gia a D. Vital e, posteriormente, a D. Macedo, aviso que lhe dava provimento, ordenando que fosse cumprida a cessação dos efeitos do ato. Tendo precedido o aviso, a consulta do conselho de Estado afirmava que "sendo de exclusiva competência do poder civil a constituição orgânica de ordens terceiras e irmandades no Brasil”, teriam os bispos "usurpado a jurisdicão do poder temporal". A esse aviso D. Vital respondia que "importa obedecer antes a Deus que aos homens", rejeitando o beneplácito imperial e considerando absurdo e herético o recurso à Coroa. O poder civil - acrescentaria D. Vital - não era autoridade em matéria religiosa, devendo, nesse aspecto, obediência à Igreja. Ao que aderia D. Macedo: "Não podendo eu, sem apostatar da fé católica, reconhecer no poder civil autoridade para dirigir as funções religiosas, [...] não posso sacrificar-lhe minha consciência e a lei de Deus”.

A pressão dos liberais levou à denúncia dos bispos sob o artigo 96 do Código Criminal, o qual, sob o título Dos crimes contra o livre exercício dos poderes públicos relacionava "Obstar ou impedir de qualquer maneira o efeito das determinações dos poderes moderador e executivo, que forem conformes a Constituição e as leis”. D. Vital foi preso em janeiro, e D. Macedo, em abril de 1874, condenados à pena de quatro anos com trabalhos forçados, causando grande comoção. Diversos abaixo-assinados, provenientes de províncias diversas e dirigidos à Câmara dos Deputados, bem como movimentos populares eclodidos em vários pontos do país contribuiram para a comutação da pena e concessão da anistia aos bispos em 1875 .

Referindo-se à Questão Religiosa, Antônio Luiz Ferreira Tinôco (1886/2003) obstava quanto ao correto enquadramento do ato dos bispos no artigo 96, já que os eclesiásticos em questão não haviam impedido que fosse cumprida a Resolução Imperial, tendo-se limitado a não obedecê-la - o que seria melhor enquadrado noutro artigo. ${ }^{17} \mathrm{~A}$ tal consideração adiciona, a título de jurisprudência:

A questão, pois, parece-me meramente espiritual, e, se não fosse, e a autoridade temporal podesse nella ingerir-se, o acto dos juizes de direito, levantando os interdictos, teria necessariamente produzido os seus effeitos. A Resolução

17 " [...] nesse caso, sendo os actos por elles praticados de desobediencia, devia a pronuncia, na hypothese de ter cabimento, ser no art. 128 do Cod. Crim. Assim votaram os Exms. Ministros Albuquerque e Mariani" (TINÔCO, 2003, p. 171). 
Imperial, ordenando em materia espiritual, não podia ser considerada ordem legal, e, conseguintemente, a desobediencia dos Bispos não podia constituir crime, afim de lhes ser applicada a pena do art. 128 do Cod. Criminal (TINÔCO, 2003, p. 171).

Acrescentem-se, ao lado dessas considerações de Ferreira Tinôco, interpretações de historiadores contemporâneos que, debruçando-se sobre esse expressivo evento, entreveem no regalismo do Estado a interferência indevida do poder temporal nos assuntos eclesiásticos:

Tanto Dom Vital quanto Dom Macedo Costa, nas suas Pastorais, faziam questão de acentuar que não haviam subvertido a ordem legal. Tinham apenas ficado com a Igreja, com o Papa, numa questão de ordem puramente espiritual. Não eram rebeldes; pelo contrário, eram fiéis à ortodoxia católica. Haviam baixado o Interdito sobre as Irmandades, mas na parte que lhes dizia respeito. $\mathrm{O}$ governo, sim, invadia e desrespeitava as determinações dos Bispos, porque estes ficaram na esfera de sua competência (PEREIRA, 1970, p. 88).

Conjugados dessa forma fatos e atores, a Questão Religiosa coloca em evidência os elementos constitutivos das relações entre as instituições no contexto específico de fusão dos poderes temporal e espiritual nas mãos do Estado. Da frente liberal, que aliava-se à atitude regalista do Estado Imperial brasileiro do século XIX, o grão-mestre Saldanha Marinho (1872 apud FRAGOSO, 1980, p. 188) expressava o posicionamento típico daqueles que se opunham ao ultramontanismo, o qual restava inconciliável com as ideias modernas: "Escolhamos liberdade ou fogueira; constituição política ou Syllabus; liberdade de consciência e de cultos, ou Igreja privilegiada, audaciosa, caprichosa, intolerante; chefe nacional, ou Pio IX; liberal ou ultramontano; Brasil ou Roma” .

À primeira vista, o desfecho do conflito parece dar a impressão de uma vitória do Governo Imperial. Uma análise mais refletida, porém, permite conceber a Questão Religiosa como uma forte e bem sucedida reinvindicação por autonomia da parte de um poder espiritual subsumido ao temporal. Ou, ainda, uma culminância coerente considerando o momento em que vivia a Igreja no Brasil, a qual concentrava esforços com vistas a tornar-se mais ortodoxa. Nesse sentido, 
uma autoconsciência de portadora da verdade e de paladino da redenção não se deixava coexistir com uma situação de submissão a um outro poder que não fosse o espiritual. Compreende-se, por conseguinte, a luta pela autonomia que já vinha travando os eclesiásticos ultramontanos antes da eclosão do conflito. Cite-se, por exemplo, o arcebispo da Bahia, D. Romualdo Seixas, o bispo de Mariana, Dom Antônio Viçoso, bem como o bispo do Pará envolvido no conflito, D. Macedo Costa.

Com efeito, o conflito consistiu num passo importante - porém inconsciente - em direção à autonomização das distintas esferas que se interpenetravam no período que antecedeu o advento da República e a separação oficial entre Igreja e Estado. Apontava, dessa maneira, para a posterior condição do Estado, o qual se eximia de suas prerrogativas em matéria religiosa. Assim determinava o artigo primeiro do Decreto no 119-A, de sete de janeiro de 1890.

Art. $1^{\circ}$. É prohibido á autoridade federal, assim como á dos Estados federados, expedir leis, regulamentos, ou actos administrativos, estabelecendo alguma religião, ou vedando-a, e crear diferenças entre os habitantes do paiz, ou nos serviços sustentados á custa do orçamento, por motivo de crenças ou opiniões philosophicas ou religiosas.

Ao requererem autonomia na jurisdição dos assuntos religiosos - reivindicação que se tornou mais vigorosa nos quadros do conflito em questão - os eclesiásticos, sem o saber, abriam largos caminhos em direção à secularização do Brasil em seu sentido macro: autonomização das esferas. E o faziam a partir de sua autoconsciência de missão, a partir de interesses religiosos, portanto.

Vislumbram-se nessa articulação de eventos assim interpretados, as consequências inesperadas - e, de certa forma, indesejadas - da ação. A exemplo dos resultados culturais da Reforma, imprevistos e não desejados pelos reformadores (WEBER, 2004), tampouco eram previstos ou desejados pelos eclesiásticos envolvidos na Questão Religiosa os resultados culturais para os quais contribuiram suas ações. O próprio Syllabus apontava para um caminho contrário àquele que efetivamente se traçava - com a colaboração ativa da própria Igreja brasileira! - no Brasil das últimas décadas do século XIX: percorriam-se trilhas que terminavam nos "erros da modernidade" denunciados pelo compêndio. 
Cumpre salientar, ainda, que o conflito contribuiu para enfraquecer as bases de sustentação do padroado, manchando-lhe a aura sagrada. Para aqueles de tendência liberal, a atuação do governo no conflito fora fraca. Para os fiéis urbanos e alfabetizados arregimentados nas fileiras ultramontanas, fora arbitrária. Para a maioria da população, a grande massa que praticava ainda uma religiosidade festiva, mágica e irreverente - permanência das interpenetrações simbólicas do período colonial -, o governo fora impiedoso. De forma geral, os sentimentos gerados nos diversos estratos da sociedade se entendem nos quadros de perda da sacralidade que envolvia o trono. O desfecho do conflito, portanto, estabelece afinidades com as transformações que se processavam nas representações da autoridade constituída, a qual se dessacralizava paulatinamente. Constituía-se, dessa maneira, a base de sentido compartilhado na qual se sustentaria a extinção oficial do padroado, conforme determinava o art. $4^{\circ}$ do Decreto $n^{\circ} 119-\mathrm{A}$, o mesmo decreto citado anteriormente, de sete de janeiro de 1890: "Art. $4^{\circ}$. Fica extinto o padroado com todas as suas instituições, recursos e prerrogativas".

Ressalte-se que em alguns setores do pensamento católico, bem como nas visões de mundo compartilhadas nos quadros do catolicismo popular, persistia o caráter sagrado da monarquia, em detrimento da República ímpia instaurada. Cite-se um grupo de leigos católicos conhecidos por sua luta pelo fortalecimento da fé, contra o laicismo da República. Dentre eles destacam-se Joaquim Nabuco, Carlos de Laet, Eduardo Prado, Afonso Celso, Brasílio Machado, João Mendes Júnior e o Conde de Sabóia. É expressiva dessa luta o discurso "A instrução e educação cristã" de Carlos de Laet (1910 apud AZZI, 1994, p. 76), no Segundo Congresso Católico Brasileiro de 1910, no qual rei e Deus são articulados lado a lado, como elementos de um terreno sagrado:

A verdade, a triste realidade que vos não devo disfarçar, é que no momento em que vos falo, lenta, mas formidavelmente vai progredindo na sua invasão, a tentativa dos que bem nítido e claro têm definido o seu lema: Reconstituir a sociedade sem rei e sem Deus. A primeira parte já está feita. Mas não lhes basta: é a segunda que ora almejam. Mas essa, confiadamente o espero, nós lha disputaremos palmo a palmo, defendendo o terreno sagrado do nosso ideal, o campo das nossas tradições, o coração de nossos filhos, o futuro de nossa Pátria, que não seria mais o Brasil se não fora a Terra de Santa Cruz. 
Trono e altar mantinham-se indissociáveis no imaginário social, o que se pode entrever no estribilho do Hino Oficial dos Congregados Marianos, presentes nos colégios católicos e nas paróquias: "O inferno ruge, enfurecido, O Altar e o Trono quer destruído. ${ }^{18}$

De acordo com tal conjugação de símbolos, as forças malignas que destituíram o trono são as mesmas que avançavam contra o altar. $\mathrm{O}$ caráter sagrado do trono estava, dessa forma, implícito ao lado do caráter sagrado do altar. Afinal, era contra ambos que investia o inferno.

No catolicismo popular ${ }^{19}$ ou rústico, como o denominou Maria Isaura Pereira de Queiroz (1973), vislumbra-se não somente a reprovação do rompimento com a monarquia; mas, sobretudo, a reprovação do rompimento com a extinta tradição de Cristandade, em cujo bojo sociedade civil e comunidade de fiéis formavam uma única entidade, estando os chefes políticos e religiosos em íntima união e colaboração, sob a égide do padroado. Ressalte-se, nesse tipo de movimento católico popular do final do século XIX e início do século XX, o caráter de religiosidade mágica e o de religiosidade de massa que o caracterizam; geralmente marcado pela posição central do líder carismático, um autêntico profeta que, embuído de características extraordinárias, visava à redenção, à renovação, à restauração de uma situação anterior, quase sempre evidenciando traços de messianismo e milenarismo.

${ }_{18}$ Azzi (1981) acrescenta que tais manifestações mantinham-se no mesmo conjunto de significados que se produziram sob o título de teologia da realeza de Cristo, cujo fundamento foi a doutrina de Cristo Rei, refletindo a nova situação da Igreja sob o pontificado de Pio IX.

${ }^{19}$ Concebido em contraposição ao catolicismo oficial, no catolicismo popular as crenças e as práticas religiosas são menos dependentes da ação dos agentes eclesiásticos, representantes institucionais do catolicismo oficial. Tais práticas e crenças do catolicismo popular são em grande medida produzidas e adquiridas coletivamente no convívio comunitário, enquanto no catolicismo oficial centraliza-se em especialistas a produção e reprodução de bens religiosos. O catolicismo popular é quase sempre produção de classes subalternas, as quais dão primazia a traços selecionados do catolicismo oficial, muitas vezes renovando-lhes o sentido na produção das crenças e práticas compartilhadas. Cf. Religião e dominação de classe, de Pedro A. Ribeiro de Oliveira. 
Característico daquele pensamento próprio de religiosidade popular foi o movimento em Canudos, no sertão da Bahia, reunido ao redor de Antônio Conselheiro. Citem-se, ainda, o de Juazeiro do Norte, no Ceará, tendo no seu centro o padre Cícero Romão Batista; e o do Contestado, na região fronteiriça entre o Paraná e Santa Catarina, em grande medida fundado na atividade e vida dos monges João e José Maria. ${ }^{20}$ Um olhar mais detido a tipo de religiosidade popular, será dirigido ao movimento de Canudos.

Em sua prédica sobre a República, Antônio Conselheiro mostrava nítida oposição ao novo tipo de governo instaurado, pois era contra a religião, "ludíbrio da tirania para os fiéis":

Agora tenho de falar-vos de um assunto que tem sido o assombro e o abalo dos fiéis, de um assunto que só a incredubilidade do homem ocasionaria semelhante acontecimento: a república, que é incontestavelmente um grande mal para o Brasil que era outrora tão bela a sua estrela. Hoje, porém, foge toda a segurança, porque um novo governo acaba de ter o seu invento e do seu emprego se lança mão como meio mais eficaz e pronto para o extermínio na religião. Admiro o procedimento daqueles que têm concorrido com o seu voto para realizar-se a república, cuja idéia tem barbaramente oprimido a Igreja e os fiéis (NOGUEIRA, 1997, p. 185).

Note-se que, ao reprovar a República, concentra-se na pessoa do presidente, como se nele se depositasse toda iniquidade. Assim o fazia tendo como referência o governo anterior, sacralizado na pessoa do monarca: "[...] movido pela incredulidade que tem atraído sobre ele toda sorte de ilusões, entende que pode governar o Brasil como se fora uma monarca legitimamente constituída por Deus [...] Oh! Homem incrédulo, quanto pesa a tua incredulidade diante de Deus" (NOGUEIRA, 1997, p. 186).

Considerando a República ilegítima, contrapunha-a à legitimidade sagrada da monarquia deposta:

\footnotetext{
${ }^{20}$ Obras importantes foram escritas sobre cada um desses três movimentos: sobre Canudos, a obra clássica de Euclides da Cunha, Os Sertões; sobre Pe. Cícero, Milagre em Juazeiro, de Ralph della Cava; sobre o Contestado, Os errantes do novo século, de Douglas Monteiro e Messianismo e Conflito Social, de Maurício Vinhas de Queiroz.
} 
Quem não sabe que o digno príncipe, o Senhor Dom Pedro $3^{\circ}$ tem poder legitimamente constituído por Deus para governar o Brasil? Quem não sabe que o seu digno avô o Senhor Dom Pedro $2^{\circ}$, de saudosa memória, não obstante ter sido vítima de uma traição a ponto de ser lançado fora de seu governo, recebendo tão pesado golpe, que prevalece o seu direito e, conseqüentemente, só sua real família tem poder para governar o Brasil? (NOGUEIRA, 1997, p. 187).

O restabelecimento da condição anterior, visando a corrigir caminhos errados e trazer a sociedade aos desígnios de Deus, típico da ação do profeta, é explícito nos termos de Conselheiro, condenando a República e requerendo a restauração da monarquia: “[...] é erro daquele que diz que a família real não há de governar mais o Brasil [...] A República há de cair por terra para confusão daquele que concebeu tão horrorosa idéia" (NOGUEIRA, 1997, p. 193).

Arrasado o arraial, em meio a cartas e diversos papéis escritos, encontravam-se "os desgraciosos versos encontrados", como os chama Euclides da Cunha (2002, p. 332-333). Resumindo a "psicologia da luta”, pode-se entrever nos versos a sacralização da monarquia e a demonização da República:

Sahiu D. Pedro segundo

Para o reyno de Lisboa

Acabosse a monarquia

O Brazil ficou atôa!

Garantidos pela lei

Aquelles malvados estão

Nós temos a lei de Deus

Elles tem a lei do cão!

Bem desgraçados são elles

Pra fazerem a eleição

Abatendo a lei de Deus

Suspendendo a lei do cão!

O Anti-Christo nasceu

Para o Brazil governar

Mas ahi está o Conselheiro

Para delles nos livrar!

Visita nos vem fazer

Nosso rei D. Sebastião.

Coitado daquelle pobre

Que estiver na lei do cão! 
A República está sob a lei do cão. A Monarquia está sob a lei de Deus. Cumpre restaurar a monarquia, portanto. Eis a missão, a qual se apresenta em termos apocalípticos. $\mathrm{O}$ caráter messiânico do movimento se faz nítido nos versos, recuperando o antigo Sebastianismo. ${ }^{21}$ Aproxima-se a redenção, a qual coincide com o juízo: ai daquele que estiver na lei do cão (o Anticristo, que não vai perdurar). Os sinais dos tempos antecipavam o juízo: a República é resultado da apoteose do pecado, apontando para o desfecho da batalha travada entre a luz e as trevas. "O rebelado arremetia com a ordem constituída porque se lhe afigurava iminente o reino de delícias prometido. Prenunciava-o a República - pecado mortal de um povo - heresia suprema indicadora do triunfo efêmero do Anti-Cristo", adiciona Euclides da Cunha (2002, p. 332).

Entretanto, a dissolução da monarquia era um fato, assim como também o era a dissipação da aura sagrada que a envolvia. As permanências e continuidades, nas ideias do povo, dos elementos constitutivos da tradição do padroado, unindo o altar ao trono, iam, dessa forma, sendo eliminadas à maneira do aniquilamento do arraial de Canudos.

Os sentidos nucleares relativos ao processo de autonomização das esferas a secularização, em sua acepção macro - que efetivamente se configuram no Brasil das últimas décadas do século XIX não encontram contrapartida nas representações partilhadas pelas massas espalhadas ao longo do território nacional. Não há uma homogeneidade de sentimentos orientada para a perda efetiva do domínio do sagrado sobre outras esferas. Muito embora desvinculado de seu sentido religioso original, o exercício do poder por uma autoridade constituída mantinha-se atado ao sagrado, despertando a reverência e a devoção características do tipo de religiosidade mágica, iconolátrica e messiânica, própria do catolicismo popular brasileiro.

${ }^{21} \mathrm{O}$ Sebastianismo refere-se à crença que surgiu em Portugal depois do desaparecimento do rei D. Sebastião na batalha de Alcácer Quibir, em 1578. Segundo o pensamento que engendra, acreditava-se na volta de um rei salvador, o qual resgataria o reino de Portugal do jugo dos castelhanos, restaurando a honra e a soberania perdidas. 


\section{Conclusão}

As considerações reunidas neste artigo contribuem para perceber que a aproximação analítica do processo de secularização requer cautela e profundidade, sobretudo porque lida com um daqueles processos que, devido a sua complexidade, exigem que sejam tomados como individualidades históricas. Considerando-se especificamente o processo de secularização da esfera política no Brasil, por meio do estudo dos eventos e episódios aqui colocados em destaque, é possível identificar sinais da autonomização da esfera política em relação à religião. No entanto, considerando-se a política numa perspectiva mais abrangente, de maneira que leve em conta a circulação do poder ao longo da configuração social brasileira da segunda metade do século XIX, permanências e continuidades diversas são percebidas, principalmente quando se colocam em perspectiva as relações entre a dimensão do sagrado e as representações sobre os poderes constituídos. Em outras palavras, ao mesmo tempo em que se pode vislumbrar a disjunção entre os poderes espiritual e temporal, como eram chamados no século XIX, é possível perceber que as influências mútuas entre as esferas não se dissipam, mas permanecem, possibilitando as novas configurações que se desenharão nas décadas seguintes.

\section{Autonomization of spiritual and secular powers in Brazil of the nineteenth century: extinction of patronage and the secularization of political sphere}

\section{Abstract}

Aspects of secularization of the political sphere in Brazil are put in perspective pointing out the relation between the autonomization of epiritual and secular powers and the extinction of patronage. Mainly during the second half of nineteenth century historical circumstances and events such as the quarel in defense of patronage as well as ultramontane ideas explicited in Religious Issue episode contributes to the understanding of ruptures and permanences in the fields of political ideas and social practices, what allows the elucidating of the process of autonomization of polical sphere in Brazil as a historial individuality. A special feature of this historical individuality is the existence of asynchrony between the social representations and practices of popular Catholicism and the autonomization of political sphere in relation to religion. 
Keywords: Secularization. Patronage. Ultramontanism. Religious issue. Popular catholicism.

\section{Referências}

AZEVEDO, T. Igreja e Estado em tensão e crise: a conquista espiritual e o padroado na Bahia. São Paulo: Ática, 1978.

AZZI, R. A teologia no Brasil: considerações históricas. In: PELAEZ, A. C. et al. História da teologia na América Latina. São Paulo: Paulinas, 1981, p. 21-43.

AZZI, R. A cristandade colonial: um projeto autoritário. São Paulo: Paulinas, 1987.

AZZI, R.. O altar unido ao trono: um projeto conservador. São Paulo: Paulinas, 1992.

AZZI, R.. O estado leigo e o projeto ultramontano. São Paulo: Paulus, 1994.

BARBOSA, R. Prefácio. In: DOLLINGER, J. J. I. V. O papa e o concílio. Tradução, prefácio e introdução de Rui Barbosa. Londrina: Leopoldo Machado, 2002, p. 11-23.

BERGER, P. O dossel sagrado: elementos para uma teoria sociológica da religião. São Paulo: Paulus, 1985.

BOXER, C. R. O império marítimo português 1415-1825. São Paulo: Companhia das Letras, 2002.

CASTELLANI, J. Os maçons e a questão religiosa. Londrina: Trolha, 1996.

CUNHA, E. Os sertões. In: SANTIAGO, S. (Coord.). Intérpretes do Brasil. Rio de Janeiro: Nova Aguilar, 2002.

DELLA CAVA, R. Milagre em Juazeiro. Rio de Janeiro: Paz e Terra, 1977.

DOBBELAERE, K. Secularization: a multi-dimensional concept. Current Sociology, Londres, v. 29, n. 2, p. 1-203, 1981.

DOBBELAERE, K. Towards an Integrated Perspective of the Processes Related to the Descriptive Concept of Secularization. Sociology of Religion, v. 60, n. 3, p. 229247, 1999. doi:10.2307/3711935. 
FRAGOSO, H. A Igreja na formação do Estado liberal (1840-1875). In: BEOZZO, J. O. (Coord.). História da Igreja no Brasil. Petrópolis: Vozes, 1980. v. 2.

HAUCK, J. F. A Igreja na emancipação (1808-1840). In: BEOZZO, J. O. (Coord.). História da Igreja no Brasil. Petrópolis: Vozes, 1980. v. 1.

LACOMBE, A. J. Ensaios brasileiros de história. São Paulo: Nacional, 1989.

LARA, T. A. Tradicionalismo católico em Pernambuco. Recife: Massangana, 1988.

MARRAMAO, Giacomo. Céu e terra: genealogia da secularização. São Paulo: UNESP, 1997.

MENCK, J. T. M. O parlamento imperial, a liberdade religiosa e as relações Estado Igreja no Brasil (1823 - 1889). 1995. Dissertação (Mestrado)-Universidade de Brasília, Brasília, 1995.

MONTEIRO, D. T. Os errantes do novo século: um estudo sobre o surto milenarista do Contestado. São Paulo: Duas Cidades, 1974.

NEVES, G. P. E receberá mercê: a mesa da consciência e ordens e o clero secular no Brasil - 1808-1828. Rio de Janeiro: Arquivo Nacional, 1997.

NOGUEIRA, J. C. A. António Conselheiro e Canudos: revisão histórica. São Paulo: Atlas, 1997.

OLIVEIRA, P. A. R. Religião e dominação de classe: gênese, estrutura e função do catolicismo romanizado no Brasil. Petrópolis: Vozes, 1985.

PASTORAL Coletiva do Episcopado Brasileiro. In: A Igreja na República. Brasília: Universidade de Brasília, 1981, p. 17-58.

PEREIRA, N. Conflitos entre a Igreja e o Estado no Brasil. Recife: Universidade Federal de Pernambuco, 1970.

PRADO JUNIOR, C. Formação do Brasil contemporâneo. In: SANTIAGO, S. (Coord.). Intérpretes do Brasil. Rio de Janeiro: Nova Aguilar, 2002.

QUEIROZ, M. I. P. O campesinato brasileiro: ensaios sobre civilização e grupos rústicos no Brasil. Petrópolis: Vozes, 1973. 
QUEIROZ, M. V. Messianismo e conflito social: a guerra sertaneja do Contestado: 1912-1916. São Paulo: Ática, 1977.

TINÔCO, A. L. F. Código criminal do império do Brazil annotado. Brasília: Senado Federal, 2003.

VIEIRA, D. G. O protestantismo, a maçonaria e a questão religiosa no Brasil. Brasília: Universidade de Brasília, 1980.

VILLAÇA, A. C. História da questão religiosa no Brasil. Rio de Janeiro: Francisco Alves, 1974.

VILLAÇA, A. C. O senador Cândido Mendes. Rio de Janeiro: EDUCAM, 1981.

WEBER, M. A ética protestante e o "espírito" do capitalismo. São Paulo: Companhia das Letras, 2004. 